\title{
The Casualty Loss Deduction and Consumer Expectation: Section 165(c)(3) of the Internal Revenue Code
}

Section 165 (c)(3) of the Internal Revenue Code provides for a deduction of "losses of property not connected with a trade or business, if such losses arise from fire, storm, shipwreck, or other casualty" and if, under section 165(a), they are "not compensated for by insurance or otherwise." 1 The casualty loss provision is of ancient lineage in the tax law; the first such deduction, for losses arising from "fires [or] shipwreck," was included in the income tax provision of the 1867 internal revenue statute. ${ }^{2}$ In 1870 the deduction was extended to cover losses from "floods."3 The 1894 income tax, held unconstitutional by the Supreme Court, 4 reworded the deduction to cover losses from "fires, storms, and shipwreck."5 Similar language was used in the 1913 Act." The term "other casualty," source of the doctrinal complications which are the subject of this comment, was first included in 1916.7

There is virtually no legislative history on any of these casualty loss provisions. The most likely explanation is simply that Congress was actuated by a notion of fairness; it sought to reduce the tax burden on a person whose income does not reflect his economic position because his assets have been destroyed during the taxable year. The archetypical case is that of the taxpayer whose uninsured home and personal property are destroyed as a result of natural disaster; his income during the

1 The general rule of $\$ 165$ of the 1954 Internal Revenue Code allows as "a deduction any loss sustained during the taxable year and not compensated for by insurance or otherwise." This comment deals only with the treatment of individuals under subsection (c)(3). The first $\$ 100$ of any such loss is excluded from the deduction.

2 Revenue Act of 1867, ch. 169, § 13, 14 Stat. 478. "And in addition to one thousand dollars exempt from income tax ... losses actually sustained during the year arising from fires, shipwreck, or incurred in trade . . . the amount actually paid by any person for the rent of the house or premises occupied as a residence for himself or his family; the amount paid out for usual or ordinary repairs: Provided, That no deduction shall be made for any amount paid out for new buildings, permanent improvements or betterments, made to increase the value of any property or estate . . .."

3 Revenue Act of 1870, ch. 255, \& 9, 16 Stat. 258.

4 Pollack v. Farmers' Loan and Trust Co., 157 U.S. 429 (1895).

5 Revenue Act of 1894, ch. $349, \S 28,28$ Stat. 553. The deduction was also amended to read "not compensated for by insurance or otherwise" for the first time.

6 Revenue Act of 1913, ch. 16, § IIB, 38 Stat. 167.

7 Revenue Act of 1916, ch. 463, §5(a), 39 Stat. 759. 
taxable year, unlike that of other taxpayers, is not even a rough measure of his ability to pay taxes at the end of the year. ${ }^{8}$ While the categories of "fire" and "storm" cover many such situations, Congress in 1916 (and in reenacting the provision thereafter) apparently concluded that a general category was needed to assure equitable treatment to taxpayers suffering similar losses not included in the enumerated categories.

But it is easier to add "other casualty" than to define its ambit. Did Congress intend that all casualties be deductible or only those similar to "fire, storm, [and] shipwreck?" If the latter, what are the similarities among the three which define "other casualty?" And what additional gloss on the statutory language is needed to prevent fraudulent claims? These are the basic questions which the courts have grappled with in this area. They have had little to work with-a sloppily drafted statute and a vague notion of granting relief to stricken taxpayers do not constitute a tax policy. It is not surprising, therefore, that the courts have produced a litany, invoked to justify ad hoc characterizations of disparate factual situations, rather than a comprehensive doctrine.

It was established relatively early that the proper approach to the "other casualty" language was through the ejusdem generis rule of statutory construction. But such an analysis was just the beginning of the problem, as the leading case asserting the ejusdem generis principle reveals. Shearer $v$. Anderson ${ }^{9}$ involved an action by a taxpayer to recover the taxes he had paid because of disallowance of his claim for a deduction of the cost of repairing his automobile, which his chauffeur had overturned while driving on an icy road. The district court gave judgment on the pleadings for the Commissioner, reasoning that the proximate cause of the damage was not a storm or similar casualty, but faulty driving by the chauffeur. ${ }^{10}$ The district court utilized ejusdem generis to limit "other casualty" to damage stemming from natural, as opposed to human, causes. On appeal, the Second Circuit reversed, holding that

An automobile wreck may be, and under this complaint was, a casualty in closest analogy to a shipwreck, a casualty clearly ejusdem generis. ... [A]s "casualty" expresses rather the result than the cause of the damage, that is, the wreck itself rather than the lightning, storm, or the negligence or fault of some person, so the "other casualty" is at least as clearly ejusdem generis with shipwreck as with fire or storm. ${ }^{11}$

8 This immediate concern with the welfare of the homeowner was revealed in the 1867 act, note 2 supra, where the rent and "usual or ordinary" repairs were also deductible items-in contrast to the present law. See INT. REv. CoDE of 1954, § 262.

916 F.2d 995 (2d Cir. 1927).

1013 F.2d 258 (S.D.N.Y. 1926).

11 16 F.2d 995, 996 (2d Cir. 1927). The cause and result distinction which the Shearer 
The court carried the analogy to "shipwreck" further, reasoning that only damage, and not total loss, to the ship is required; that the loss need not be caused by storm or other natural causes; and that the ship may be a "pleasure yacht" unconnected with trade or business. ${ }^{12} \mathrm{Com}$ pleting the analogy, the court held that an automobile used for recreation and convenience "would seem most closely analogous to a pleasure yacht"; and since Congress made damage to the latter deductible, "other casualty" should be construed to include damage to the former. ${ }^{13}$

The Shearer court severely restricted the applicability of a fault concept to the shipwreck analogy it drew. ${ }^{14}$ But there is little indication of the test which the court itself would apply to define a "casualty" loss, especially since the analogy to a shipwreck does not seem particularly helpful in the analysis of later cases, where the presence or absence of negligence is of marginal significance. It remained for later courts to determine when the shipwreck analogy was to be used. ${ }^{15}$

Faced with the text of section $165(\mathrm{c})(3)$ and its antecedents, one may readily conclude that Congress was concerned with providing relief for individuals whose personal property was lost or damaged because of a shipwreck, as much or more than it was with providing deductions for those who run pleasure yachts aground. It is difficult to understand why a deduction for personal goods lost or damaged in transit should be limited to those carried on ships which wrecked in passage, since even in 1867 railroads and wagons were probably more important

court attempted to make, has not been a significant factor in later analysis of the deduction. Indeed, one may question whether "shipwreck" is meant to state a result rather than a cause. See text at notes 17-19 infra. As shall be apparent in later discussion, when there is no direct analogy to "fire," "storm," or "shipwreck" to aid the courts, the cause-result distinction loses any relevance it might have had in Shearer.

12 Id. Although the court did not say so, there is actually no need for the deduction unless it is a "pleasure" yacht, since business losses were (and are) separately deductible. See 1916 Revenue Act, ch. 463, § 5(a), 39 Stat, 759; INT. REv. CODE OF 1954, § 165(c)(2).

13 The IRS acquiesced in this case. T.T. 2408, VII-I Cum. BuLc. 85, 86 (1928):

... There appears to be some uncertainty in the Bureau as to whether a loss should be allowed as a deduction where damage to a pleasure automobile results from faulty driving on the part of either or both of the drivers rather than from the condition of the road ..... In accordance with the opinion [Shearer] of the court , ..., it is held that a loss occasioned by damage to an automobile maintained for pleasure where such damage results from the faulty driving of the taxpayer . . . is a deductible loss in the computation of net income . . . .

14 According to the court, fault was irrelevant as long as the shipwreck was "not caused by the willful act or neglect of the owner, or of one acting in his behalf." 16 F.2d 995, 997 (2d Cir. 1927).

15 See Harry Heyn, 46 T.C. 302 (1966), where the Tax Court found a landslide to be similar to a shipwreck. It was unclear and ultimately irrelevant in shearer whether the loss was caused by the storm which made the road icy (and caused a sudden drop in temperature which froze the engine block) or the wreck of the car itself. The holding was in the alternative, the court emphasizing the shipwreck analogy in order to dispose of the negligence issue. 
freight-haulers and then (as now) all modes of transportation lost or damaged an appreciable amount of cargo even without collision; yet that was apparently what the statute said.

It seems clear that the addition of "other casualty" did not create a separate category for deductions, but the amendment did broaden the type of collision which can produce a casualty loss. Thus, it did not, according to the Tax Court, create a more general deduction for goods lost in transit. The case so holding is Bercaw v. Commissioner, decided in 1947. ${ }^{16}$ The taxpayer had attempted to deduct the value of personal property which was lost either during storage in a commercial warehouse or during a rail shipment from California to Virginia. The court might have held that the taxpayer failed to establish the taxable year in which the loss occurred, since the applicable provision was identical to section $165(c)(3)$ in requiring that the loss be "sustained during the taxable year." 17 Instead, the Tax Court chose a broader ground on which to deny the deduction, holding that

losses of personal property arising in storage or transit and otherwise unexplained, as in the instant case, are not the result of any sudden, unexpected or unusual cause but are more on the side of the commonplace and usual. We therefore do not consider the loss here as arising from "other casualty" . . . .18

On a theoretical basis, Bercaw is difficult to explain. There seems to be no good reason to reject a shipwreck analogy in Bercaw, where the loss may have been "commonplace" but the taxpayer's negligence was not involved, while accepting such an analogy in Shearer, which also involved a commonplace loss (even in 1916, when the accident occurred) but was coupled with negligence on the part of the taxpayer's servant. The explanation is historical; in the twenty years between Shearer and Bercaw, the courts articulated a test-whether the loss was "sudden, unexpected or unusual"19-which displaced attempts at reasoning by direct analogy between the event in question and the terms of the statute.

\footnotetext{
106 CCH Tax Ct. Mem. 27 (1947).

17 The taxpayer had stored a number of personal items, such as cavalry breeches, army slacks and a boot jack, in a warehouse in California in 1933 or 1934. In September 1941 he requested the warehouse to ship him these goods in Virginia. Upon receiving the goods in November of the same year, the petitioner noticed that some of the boxes had been broken open and several items (worth $\$ 174$ ) were missing. The taxpayer first claimed these losses under the theft deduction but the court denied the claim because there was insuffcient evidence to prove that theft was "the exclusive possibility or probability." $6 \mathrm{CCH}$ Tax Ct. Mem. 27, 31 (1947).

$18 I d$.

$18 \mathrm{Id}$. The courts have also developed a few additional limitations, one of which was utilized in Bercaw, which will be discussed below.
} 


\section{SUdDENNESS AND Other Limitations ON THE Deduction}

Almost without exception, the case law under section 165(c)(3) and its predecessors requires that a loss be "sudden" in order to be deductible. The leading precedent is Matheson $v$. Commissioner, ${ }^{20}$ in which the Second Gircuit denied a casualty deduction for payments made by the taxpayer over a period of two years to protect a home built over water from rapid deterioration caused by corrosion and weakening of steel reinforcing rods improperly installed in the concrete foundation beams. ${ }^{21}$ Rather than apply ejusdem generis principles directly, as it had in its earlier decision in Shearer, the court attempted to distinguish a deductible casualty from depreciation caused by ordinary wear and tear, which cannot be deducted where property not used in a trade or business is involved..$^{22}$ A casualty, it held, is "an event due to some sudden, unexpected, or unusual cause." ${ }^{23}$ Matheson's deduction was denied because

the proof of any serious storm or cataclysmic operation of the elements failed. No time is satisfactorily established when any serious injury to the foundation occurred. It was never overwhelmed by any unusual thing. ${ }^{24}$

The court found "simply a steady labefaction from wind and weather more rapid than usual because of structural defects." 25

\footnotetext{
2054 F.2d 537 (2d Cir. 1931).

21 Id. at 539. The floor beams were constructed from overlapping sections of 16-foot steel bars, which were substituted for 28-foot sections when the latter were unavailable locally. As a result, the concrete was insufficiently thick where the overlapping took place: "This caused the bars to rust and corrode and converted the point where the most strength was needed in the whole structure into a point of weakness." 54 F.2d 537, 539 (2d Gir. 1931).

22 Int. Rev. Code of 1939, ch. 1, § 24(a)(1), 53 Stat. 16 (now INT. Rev. CODE of 1954, $\S 262)$.

2354 F.2d 537, 539 (2d Cir. 1931). The court cited three obscure cases to support this test: Crystal Springs Distillery Co. v. Cox, 49 F. 555 (6th Cir. 1899); Forsdick v. Board of Supervisors, 25 So. 294 (Miss. 1899); Eaton v. Glindeman, 33 Idaho 389, 195 P. 90 (1921). Of the three, only Gox deals with an Internal Revenue statute-on the taxation and regulation of alcohol. Both the statute and the cases cited in Cox place a heavy emphasis on the absence or presence of negligence. For example, in Welles v. Castles, 69 Mass. (3 Gray) 323 (1855), Chief Justice Bigelow asserted that "unavoidable casualty' . . . signifies events or accidents which human prudence, foresight and sagacity cannot prevent." In Cox, the court asserts that "the warpage and injury to said barrels containing the spirits" were caused by excessive summer heat and "undiscoverable worm-holes," neither of which was unforeseeable. $49 \mathrm{~F}$. at 559. Deterrence through severe enforcement of the relevant statutes is a necessary function of taxpayer's dealings in distilled spirits. In the personal deduction situation, there is no potentially malevolent force to be controlled; in fact, the deductions are a legislative endeavor to ease the burden of severe economic loss.

2454 F.2d at 539.

25 Id.
} 
In Rosenberg $v$. Commissioner, ${ }^{26}$ decided 21 years after Matheson, the Eighth Circuit attempted to return to the reasons the Second Circuit had given for the suddenness test in upholding a deduction for termite damage to a house in the face of adverse precedents from the Ninth Circuit and the Second Circuit itself. ${ }^{27}$ In Rosenberg, the court asserted that "suddenness is a comparative term"; the decisive element for comparison is not the instantaneous destruction resulting from a collision, but the normal life span of the building:

Comparatively speaking, an invasion of a colony of termites which destroys the timbers of a building in a month, three months, or a year, is a sudden destruction when from natural depreciation it would have required from 25 to 50 years or longer for them to have been substantially injured..$^{28}$

Because the taxpayer in Rosenberg had inspected his home for termites in the very year of destruction, the time of damage could be established within a six-month span. The court's comparative suddenness test, therefore, was not as much of a refinement of the Matheson test as it may have appeared, since the damage in Matheson occurred over a period of at least two years. Nevertheless, the Commissioner did not acquiesce in the Rosenberg decision; the IRS denies termite loss deductions because the speed with which termites attack wood is too slow to come within the generally recognized definition of suddenness. ${ }^{29}$ While the courts occasionally follow Rosenberg in termite cases with virtually identical

20198 F.2d 46 (8th Cir. 1952).

27 Fay v. Helvering, 120 F.2d 253 (2d Cir. 1941); United States v. Rogers, 120 F.2d 244, modified by 122 F.2d 485 (9th Cir. 1941). In the latter case, actor Will Rogers was forced to raze his residence upon discovery of extensive termite damage. A few years earlier, he had spent almost $\$ 50,000$ improving the house.

28198 F.2d 46, 50 (8th Cir. 1952). The part of the home which was affected was determined to consist of "an area of five or six feet adjacent to the point of entry of the termites through a small crack in the foundation. ..." Id. at 47.

29 Rev. Rul. 59-277, 1959-2 Cum. Bur.. 73 established a special category for the Rosenberg case, limiting its application to situations in which the "invasion" had been sudden. Rev. Rul. 63-232, 1963-2 CuM. BuLl. 97 reversed the earlier ruling and made all termite damage nondeductible:

Leading authorities on the subject have concluded that little or no structural damage can be caused by termites during the first two years after the initial infestation. It has been estimated that under normal conditions, if left unchecked, depending upon climate and other factors, an infestation of three to eight years would be required to necessitate extensive repairs .... Such damage is the result of gradual deterioration through a steadily operating cause and is not the result of an identifiable event of a sudden, unusual or unexpected nature ....

This ruling is in direct conflict with the earlier case of Hale v. Welch, 38 F. Supp. 754 (D. Mass. 1941), where the question of termite damage qualifying for a casualty deduction was held to be "a question of fact, to be determined upon evidence properly adduced at the trial." 
facts, ${ }^{30}$ they are reluctant to import relativity into other determinations of suddenness, suggesting that they are less interested in drawing a meaningful distinction between casualties and normal depreciation than in erecting a rule that is easy to apply.

The suddenness test undoubtedly meets that criterion. Ray Durden ${ }^{31}$ is an instance of its use to support allowance of the deduction. In this case, the Tax Court held that damage caused to a house by blasting in a quarry one half-mile away was a casualty. The particular blast causing the damage had the characteristic which the Tax Court, like the Second Circuit in Matheson, saw as the "prime element" of a casualty loss"suddenness as opposed to some gradually increasing result." 32 There had been previous blasting of lesser intensity, but the court found that the damage "was not caused by any progressive deterioration of property." 33

Durden would be a more interesting case if the previous blasts had seriously weakened the house, making it susceptible to destruction by the final blast. The Second Circuit in Matheson had specifically reserved judgment on a similar hypothetical case in which a structurally-weakened house was readily destroyed as a result of a final, determinative force, implying that a sudden force, at some point during the destructive process, is necessary to trigger the casualty loss deduction. ${ }^{34}$ By this reasoning, the Durden hypothetical would qualify for a deduction. ${ }^{35}$

30 Busit v. United States, 164 F. Supp. 218 (E.D.S.G. 1958); Shopmaker v. United States, 119 F. Supp. 705 (E.D. Mo. 1953). The recent case of Herbert H. Nelson, CCH Dec. 28, 861(M), T.C. Mem. 1968-35 (1968), involved the loss of pine trees by an attack of southern pine beetles. The loss was held deductible because the beetles kill trees within 5 to 10 days, there were no known attacks by such beetles in the area (in epidemic proportions) either prior to or subsequent to the attack in question, and the loss was therefore sufficiently sudden and unexpected.

313 T.C. 1 (1944).

32 Id. at 4.

$33 I d$. For a further discussion of this case, see text at note 79 infra.

3454 F.2d 537, 539 (2d Cir. 1931). The Matheson court used "storm" as the determinative force in its hypothetical; the fact that this term is specifically enumerated in the statute is irrelevant to the question posed by the hypothetical. Until recently, loss by drought damage was one specific exception to the "sudden force" requirement. See Buttram v. Jones, 87 F. Supp. 322 (W.D. Okla. 1943); Rev. Rul. 54-85, 1954-1 CuM. BulL. 58. But see Rev. Rul. 66-303, 1966-2 Cum. BuLl. 55, where the Commissioner permitted all claims for drought damage, "as in the case of ornamental trees or shrubs progressively affected and ultimately killed from lack of water," prior to 1966 because of "the confusion and doubt" that existed in the IRS and the courts. As a result of the clarification provided by this ruling, no deduction for drought damage is now permitted.

35 In both hypotheticals, determination of the loss would create a difficult problem of proof. Helvering v. Owens, 305 U.S. 468 (1939), requires the taxpayer to prove the value of the property immediately before and after the casualty loss, so that the difference is the amount of the deduction. See IRS Pub. No. 155 (Rev. 2-59). Since the house would presumably be destroyed or seriously damaged in both hypotheticals, it would be difficult to establish its value immediately prior to the destructive event. 
A gradual loss following a sudden force would also qualify. Harry Johnston Grant, ${ }^{36}$ although arguably also explicable on the basis of comparative suddenness, illustrates this proposition. In February of 1927 the taxpayer discovered a small crack across the entire width of his lakefront property, parallel with the lake and approximately eight feet from his house. The land on the lake side of the crack sank vertically, at the rate of a few inches a day, by more than twenty-five feet within the next year. The Tax Court allowed a casualty deduction, reasoning that:

there was the unexpected, unusual, unlooked for extensive physical alteration of the earth's surface, in the nature of a catastrophe, which resulted disastrously to the petitioner. ${ }^{37}$

Although the court could not ascertain the cause of the subterranean disturbance, it did point to a time when the force first manifested itself. ${ }^{38}$

The operation of a sudden force at some time during the destructive process-either as the final event, as in the Durden hypothetical, or as the initial cause, as in Grant-seems to be the single essential element of an "other casualty." The test is often phrased, as it originally was in Matheson, in terms of the "sudden, unexpected or unusual." In most cases, however, the latter terms are surplusage; the courts may use language suggesting that expectation is the key (as in Grant) but few opinions assert that a loss must be "unexpected or unusual" before it is deductible. If this were not the case, there would be serious doubts about the deductibility of automobile accidents which, since Shearer, are "certainly in the 'other casualty' category," 39 but can hardly be termed unusual. The courts seem to assume, instead, that a casualty involving a sudden force is necessarily "unexpected" and "unusual," at least in a general sense. With a few exceptions, discussed below, the courts have not denied a claim because the loss could have (or has) happened to everyone.

This is not to say that the only test the courts apply is suddenness, but it is the primary test. A court will occasionally deny a deduction for

3630 B.T.A. 1028 (1934).

37 Id. at 1035.

s8 In a case covered directly by the "storm" category, Willard T. Burkett, $10 \mathrm{CCH}$ Tax C. Mem. 948 (1951), a deduction was allowed in 1946 for loss resulting from damage to a beach house by a hurricane in 1944 because the results were not evident until the floor boards and porch buckled and had to be replaced. The "other casualty" deduction in Grant is a logical extension of Burkett, both in terms of the ejusdem generis rule and the presence of a sudden force at the beginning of the destructive processs.

39 See John P. White, 48 T.C. 430,437 (1967). See also 88th Cong., 2d Sess., S. REP. No. 830 at $57-8$ (1964). 
a loss shown to involve a sudden force, but the reasons for denial are sometimes poorly articulated.

An example is the case of Appleman $v$. United States, ${ }^{40}$ in which the Seventh Circuit raised unexpectedness from the level of verbiage to the realm of doctrine. The taxpayers in that case had won a jury verdict allowing a casualty loss deduction based on the diminution of value of property due to the loss of elm trees from disease over a period of three years. The court could have held, as had an Ohio district court, ${ }^{41}$ that "loss occasioned by disease, however contracted, is not a casualty," 42 because it lacks suddenness. But it specifically refused to pass on the question of whether "death within a month from infection is relatively 'sudden'." 43 Instead, it reversed on the ground that "the element of unexpectedness was entirely lacking." 44 It applied ejusdem generis to derive "suddenness and unforeseeability" 45 as the common characteristics of the casualties enumerated in section $165(\mathrm{c})(3)$ :

Fire and shipwreck are undesigned, sudden and unexpected events. While storms are to a degree predictable the factors of their violence and the particular site of loss or damage are uncertain. ${ }^{46}$

Here, however, the loss of elm trees was to be expected because such losses were a common occurrence in the community:

Between fifteen and seventeen thousand elms were lost in the area-over ninety-eight percent of the elms in the community. The disease existed in the area and the evidence is that no practical means existed to effectively protect a tree from infection. ${ }^{47}$

40338 F.2d 729 (7th Cir. 1964), cert denied, 380 U.S. 956 (1965).

41 Burns v. United States, 174 F. Supp. 203 (N.D. Ohio 1959), aff'd per curiam, 284 F.2d 436 (6th Cir. 1960).

42 Id. at 210.

43338 F.2d 729, 732 (7th Cir. 1964).

44 Id.

$45 \mathrm{Id}$. at 730. This derivation is to be contrasted with the one in Matheson, where the three terms (suddenness, unforeseeability, unusualness) were written in the disjunctive form. 54 F.2d 537, 539 (2d Cir. 1931). Here, the court asserts that all three elements must be present and disqualification is based on the absence of unexpectedness. In 1953, the IRS stated the test in the disjunctive form. Rev. Rul. 79, 1953 Cum. BuLc. 41. But Mortimer Caplin asserted the contrary one year later:

"For, to support a finding of a 'casualty,' the judiciary usually requires that all three elements must be present-suddenness, unexpectedness and unusualness. In fact, the court's primary inquiry seems clearly to be on the first element, suddenness; and, where this is absent, the deduction is usually denied." Caplin, Casualty Losses: Recent Developments, 12 N.Y.U. INSTITUTE ON FED. TAXATION 525, 526 (1954).

46338 F.2d at 730-1.

47 Id. at 732 . 
In Appleman the court did not rely on the taxpayer's subjective expectation at the time the property was purchased, since the disease did not appear in the area until some years later. Nor did it rely on the taxpayer's failure to prevent the loss; on the contrary, the impossibility of protecting the trees was apparently a factor which demonstrated that the loss was expected. Thus, it was objective circumstance, rather than the taxpayer's behavior or assumption of risk, which in the Seventh Circuit's view justified denial of a deduction. Few cases go as far in rejecting a deduction on grounds of foreseeability.

Negligence does not defeat a casualty loss deduction. ${ }^{48}$ In Harry Heyn, ${ }^{49}$ the Tax Court held deductible the damage resulting from an earthslide caused by excavations for a home foundation on a steep hillside. The court explained that, even assuming the claimant had negligently ordered excavation on his property, he was entitled to a deduction:

[N] egligence [is not] a decisive factor. Automobile accidents are perhaps the most familiar casualties today. Yet the owner of the damaged vehicle is not deprived of a casualty loss deduction merely because his negligence may have contributed to the mishap....

We are unable to perceive any distinction between a casualty loss arising from an automobile collision and one resulting from a landslide..$^{50}$

In Harry Heyn, the Tax Court explicitly rejected the argument that the taxpayer should have anticipated the risk of attempting to build on a steep hillside lot with unstable soil conditions, again analogizing to an automobile accident to hold a casualty loss deductible despite the taxpayer's "having taken a calculated risk in respect of known hazards." 51

This does not mean, however, that the taxpayer's behavior is irrelevant. In Heyn itself, the Tax Court recognized a gross negligence limitation on deductibility. And in John P. White, it indicated that "the taxpayer may not knowingly or willfully sit back and allow himself

\footnotetext{
48 Shearer v. Anderson, 16 F.2d 995 (2d Cir. 1927); Anderson v. Commissioner, 81 F.2d 457, 460 (10th Cir. 1936); See also Treas. Reg. § 1.165-7(a)(3): damage to automobile caused by faulty driving of taxpayer or another driving the automobile, but not willful act or willful negligence, is deductible. In Elwood J. Clark, 5 CCH Tax Ct. Mem. 286 (1946), it was held that proof of an automobile accident established a prima facie case for the taxpayer-when the government claimed he was acting willfully.

4946 T.C. 302 (1966).

60 Id. at 308. But cf. Kipp v. Bugler, 64-2 USTC ๆ 9711 (W.D. Pa. 1964), also involving a landslide which may have been caused by excavation, where the court instructed the jury that a casualty "is an inevitable accident involving unforeseen circumstances, not to be guarded against by human agency and in which man takes no part."

51 46 T.C. 302,308 (1966).
} 
to be damaged in his property or willfully damage the property himself." 52 Feinstein $v$. United States ${ }^{53}$ is an example of a case in which such conduct defeated the deduction. In 1945, termites were discovered in the taxpayer's house, but he failed to take proper remedial steps. In 1951 he sought to take a casualty loss for termite damage. The court sustained the denial of the deduction:

Plaintiffs, faced with warning of loss and in possession of knowledge of how to prevent it, elected not to act. The result could well be anticipated. It should have been no surprise. It was not a casualty. . . .

[T]ermites were present but plaintiffs in effect hid their heads in the sand and said we will not look behind that partition, lest we have confirmed the warnings of the experts. ${ }^{54}$

Feinstein appears to be a sensible interpolation of a limitation beyond suddenness. Other limitations designed with the same goal in minddenial of spurious or fraudulent claims-may not be. One such limitation involves the loss, rather than destruction, of personal property. Bercaw, in which the goods were lost in storage or in transit, is an example of this reasoning:

Were "other casualty" delimited in its application to include ordinary, commonplace forms of loss of personal property, the resulting and [sic] practical difficulties would not be difficult to imagine. The judicial tendency to limit "other casualty" to sudden, unexpected and unusual events similar to fires, storms and shipwreck has the practical advantage of confining personal losses to somewhat dramatic settings which are susceptible to identification and verification by the administrative authorities. ${ }^{55}$

Several objections can be made to this explanation of the "other casualty" provision. First, as mentioned above, "commonplace" is not a helpful term, since automobile collisions are among the most "commonplace" and prevalent forms of loss of personal property. Second, "commonplace" is a particularly conclusory word, subject to use at will by any court not disposed to grant a deduction. Third, if "commonplace" refers to the amount of the loss, as Bercaw suggests, the statutory minimum of $\$ 100$, imposed by Congress in 1964, is a legislative deter-

5248 T.C. 430,435 (1967).

53173 F. Supp. 893 (E.D.Mo. 1954). See discussion of this case at note 78 infra. It should be noted that this case arose within the Eighth Circuit after the decision in Rosenberg. The court did not address itself to suddenness, thereby distinguishing the two cases.

$54 I d$. at 895 .

556 CGH Tax Ct. Mem. 27, 31 (1947). 
mination of the line below which the dollar amount of the loss is too commonplace to deserve consideration for deduction. ${ }^{56}$ And, at least since 1967 when the Tax Court recognized arguments similar to these and held that a casualty loss need not be "cataclysmic," the "commonplace" element of the Bercaw test has not been the law. ${ }^{57}$

The Bercaw statement concerning verification of the loss is a more reasonable policy, but one that need not be articulated quite so boldly by the courts. As a series of cases dealing with lost rings suggests, the courts make meaningless distinctions to avoid the statement that the taxpayer has not proved the loss of his property. In Edgar F. Stevens, ${ }^{58}$ the taxpayer's ring slipped off his finger into several feet of muddy water while he was duck hunting; the deduction was denied because there was no "sudden or destructive force" involved. Similarly, in Keenan $\nu$. Bowers, where the taxpayer flushed his wife's ring (which had been wrapped in Kleenex for safekeeping) down the toilet, the deduction was disallowed because the "loss lacks the element of suddenness." 59 In William $H$. Carpenter, on the other hand, where the ring was destroyed in a garbage disposal but fragments were recovered, the deduction was allowed. ${ }^{\circ 0}$ And in John P. White, where the diamond from the ring was dislodged from its setting and lost when a husband slammed the car door on his wife's hand, the loss was held deductible, since part of the ring remained.61 In both Carpenter and White, the Tax Court found the requisite suddenness.

Reliance by the courts on the taxpayer's failure to prove the fact or amount of loss would seem to be a more sensible approach to cases like Bercaw, Stevens, and Bowers than the utilization of a definition of casualty designed to distinguish the deduction from depreciation, not to distinguish casualty from loss. It seems anomalous to rely on a definition of "casualty" to serve the function which the general allocation of the burden of proof in tax deduction cases has already fulfilled. ${ }^{02}$

58 Revenue Act of 1964, P.L. 88-272, § 208(a), 78 Stat. 19. Prior to this amendment, cases involving minor claims were regularly decided against the taxpayer: Emily Marx, 13 T.G. 1099 (1949) (loss of cash from a brief case and a lunch box on the subway were not due to theft or other casualty); Luther Ely Smith, 3 T.C. 696 (1944) (payment for lost library book not a casualty); Samuel Poorman, Jx., 45 B.T.A. 73, aff'd, 131 F.2d 946 (1942) (broken eyeglasses not a casualty loss).

57 John P. White, 48 T.C. 430, 434 (1967): "To hold that a loss must be cataclysmic in order to qualify as some 'other casualty' . . . would be to limit the ... deduction to circumstances which are virtually catastrophic in character."

$586 \mathrm{CCH}$ Tax Ct. Mem. 805, 806 (1947).

ธ9 91 F. Supp. 771, 775 (E.D.S.C. 1950).

$6025 \mathrm{CCH}$ Tax Ct. Mem. 1186 (1966).

6148 T.C. 430 (1967).

62 The scope of the taxpayer's burden of proof is indicated by the following cases: Ferguson v. Commissioner, 59 F.2d 893 (10th Cir. 1932) (proof that the loss claimed is in 
A related limitation requires that the casualty, even if it meets the applicable test, have resulted in actual loss to the property, rather than only a hypothetical loss or mere fluctuation in value. This limitation has been derived from Citizens Bank of Weston $v$. Commissioner, ${ }^{63}$ in which the Fourth Circuit denied a business loss to a bank which discontinued use of its basement for storage of records and supplies because a flood raised the fear of future loss. The court held that to allow the deduction and a corresponding reduction in basis of the property, would logically require a restoration of the deduction in a later year if flood control removed the danger of future floods and other adjustments up and down to correspond to "other turns of the wheel." ${ }^{4}$ The tax law, the court held, is not designed for such a series of adjustments

to reflect the vicissitudes of the market, or the wavering values occasioned by a succession of adverse or favorable developments. [Citations] Normally, the loss involved in impaired usefulness is recognized on sale or other disposition. It may also be recognized as deductible when an event has definitely set at rest the possibility of future use. [Citation] But where, as here found, the possibility is not remote that the owner will alter its decision not to use a portion of the property for a particular purpose, no deduction is allowable. ${ }^{65}$

The Tax Court recently applied these principles in Harvey Pulvers, ${ }^{68}$ a casualty loss case. In 1963, a landslide in a hillside area destroyed two houses and damaged a third across the street and over 300 feet from the taxpayer's house. There was no physical damage to his house, or to the road. The county tax assessor reappraised the taxpayer's house at $\$ 22,150$ less than the value prior to the landslide, a diminution of roughly one-third. The taxpayer claimed a deduction based on the difference in value. The Commissioner conceded that the landslide was an "other casualty," but contended that it would not support a deduction for loss; the court agreed. It recognized that there had been a loss in fair market value immediately following the landslide, but held that

excess of any insurance or other form of compensation); Samuel Poorman, Jr., 45 B.T.A. 73 (1941) (failure to introduce any "very satisfactory proof" that loss of eyeglasses had been sustained through a casualty); Buttram v. Jones, 87 F. Supp. 322 (W.D. Okla. 1943) (failure of taxpayer to submit proper evidence of the amount of the loss); Thomas J. Draper, 15 T.C. 135 (1950) (failure to prove ownership); Ione S. Wynne, 11 CCH Tax Ct. Mem. 298, aff'd per curiam, $199 \mathrm{~F} .2 \mathrm{~d} 958$ (2d Cir. 1952) (failure to prove year in which casualty occurred).

63252 F.2d 425 (4th Cir. 1958). Whether the loss was a "casualty" was, of course, not at issue.

64 Id. at 428 .

65 Id.

6648 T.C. 245 (1967). 
there was no actual physical damage to [the] property, its use as a home was not impaired or materially changed, and certainly the possibility of its future use as such had not been ended. We look upon this diminution in value as psychological or hypothetical and due to temporary adverse buyer resistance. ${ }^{07}$

The court distinguished Stowers $v$. United States, ${ }^{68}$ in which a landslide did not damage the taxpayer's home, but "rendered [it] useless" by blocking access from a street. The district court in Stowers had relied on Citizens Bank of Weston to hold that the event had ended the possibility of future use.

The court's decision in Pulvers appears to have been justified on the facts. ${ }^{69}$ It is interesting to speculate, however, on what the result would have been had the Pulvers sold their property at a price which reflected the decreased value from the landslide. There is precedent for postponing the allowance of a casualty loss deduction until the loss, as distinguished from the injury, is "actually consummated and [becomes] ascertainable." 70 It could be argued, therefore, that sale, like impairment of value which is demonstrably permanent-such as total destruction of the asset or the cost of repair-would overcome the objection that the loss is hypothetical. The question is whether the taxpayer should be allowed a deduction for a loss in market value where there is neither total destruction to the property nor sale. This problem may be illustrated by comparing Pulvers with a case in which decreased market value is the measure of the loss sustained as the result of physical damage to the property. United States $v$. Barret, ${ }^{71}$ the leading decision on postponement of the deduction until the loss is ascertainable, is an example of the latter type of case. In Barret, the Fifth Circuit allowed the taxpayer to deduct the loss of value to residential property resulting from the death of trees damaged by freeze. The postponement of the deduction was not until the property was sold, but rather until it became clear that the trees could not be saved and were removed. As in Pulvers, the use of the property as a house was not impaired or materially changed nor was the possibility of its future use as a home ended. The

67 Id. at 249.

68169 F. Supp. 246, 248 (S.D. Miss. 1958).

69 In 1964 the taxpayers had installed a swimming pool and a rock garden on their property, at a cost of $\$ 10,000$, completely financed with a home improvement loan from a commercial bank; the city began shoring up the slide area in late 1966 (after two more minor slides); there was testimony in the case that if the condition were stabilized, the property would return to its previous value within two to five years.

70 United States v. Barret, 202 F.2d 804, 806 (5th Cir. 1953); see also Willard T. Burkett, 10 CCH Tax Ct. Mem. 948 (1951).

71 202 F.2d 804 (5th Cir. 1953). 
decreased value for which the deduction was allowed resulted from "particularly unsightly gaps in the landscaping which will require years to fill in with other trees."72 In Pulvers, on the other hand, if the city had succeeded in shoring up the hillside, the adverse effect on value would have been extinguished in a relatively short time. The Tax Court held that this losss was a mere fluctuation in value, "psychological or hypothetical and due to temporary adverse buyer resistance." 73 There is an implication that losses in value from casualties not inflicting actual physical damage upon the property, or blocking access, cannot be deductible because the loss is not a real one, but this test has little to recommend it. There is no valid reason for distinguishing loss of value from physical damage to property from loss of other components of value, assuming both result from a "sudden" force. It is true that evidence of the latter may be more speculative, but that would seem to be a proof problem that should not have bearing on the theoretical deductibility of the loss. A more plausible distinction is between losses (of whatever component of value) of relatively long duration and those likely to be relatively short-term. From that point of view, Pulvers failed to prove certainty of protracted loss of value, either because in fact the loss was a relatively brief one or because he left the issue to the speculation of the court.

The courts have not found suddenness alone a sufficient test of deductibility, although, as the ring cases show, suddenness may be manipulated to achieve desired results. In the most recent ring cases, the Tax Court, while sustaining the deduction, attempted to restate the test of "other casualty." In White, the court said;

The principle of ejusdem generis as it is presently applied does no violence to congressional intent. Its application has been consistently broadened so that wherever unexpected, accidental force is exerted on property and the taxpayer is powerless to prevent application of the force because of the suddenness thereof or some disability, the resulting direct and proximate damage causes a loss which is like or similar to losses arising from the causes specifically enumerated in section $165(\mathrm{c})(3) \cdot{ }^{74}$

Ejusdem generis has come a long way from Shearer; while the test stated in White seems reasonably comprehensive, it is ironic that the court felt compelled to state it as arising from analogy to "fire, storm, [and] shipwreck."

$72 \mathrm{Id}$. at 805 .

7348 T.C. 245,249 (1967).

7448 T.C. 430,435 (1967). 
The Gasualty Loss Deduction and Consumer Behavior

It has been suggested that the purpose of the casualty loss deduction was to mitigate the effects of the progressive rate structure of the income $\operatorname{tax}^{75}$ This was obviously not the case with the original 1867 provision, since in addition to providing the "fires and shipwreck" loss deduction, Congress also established a flat five per cent rate in that year. ${ }^{76}$ Nor does it seem likely that the deduction was retained and expanded in later years because it was regressive. The value of the deduction does increase with the taxpayer's bracket, and the amount of tax relief afforded for an identical casualty loss will be greater for the higher income taxpayer, who might be said to need it less, but this is true of any deduction, as opposed to tax credit.

One way of describing the casualty loss deduction is that it is a subsidy, equivalent to the amount of tax relief given the taxpayer, to compensate for the loss. Although the amount of the subsidy is distorted by the progressive tax rate structure, any taxpayer gets some subsidy if a casualty diminishes the value of an asset not used for income-producing purposes by more than $\$ 100$. He gets no such subsidy, however, for the aggregate wear and tear or loss on the sale of such assets, even though their impact on his net worth may be greater than that of the casualty losses sustained during the taxable year. The assumption on which this tax relief is predicated-that casualty losses have a greater impact on the taxpayer's economic status than do other decreases in the value of non-business assets-suggests that an ideal test for the scope of the deduction would focus not on an objective factor like suddenness, but on the taxpayer's expectations and behavior in consuming his property.

Implementation of such a test would require the Internal Revenue Service to consider each taxpayer's state of mind with respect to the use of his property in order to decide whether or not the damage or destruction was a normal consequence of the mode of consumption the taxpayer had elected for his property. For example, a comparison of Rosenberg ${ }^{77}$ and Feinstein ${ }^{78}$ might lead to the conclusion that each taxpayer made a conscious choice respecting the disposition of his home. Rosenberg chose to prevent damage with nondeductible personal expenses for termite inspection and extermination; he had, to that extent, decided to maintain his home for future enjoyment rather than

75 Comment, Federal Income Tax: The Dilemma of the Casualty Loss Deduction, 1961 DUKE L.J. 440.

70 Revenue Act of 1867 , ch. 169, § 13, 14 Stat. 478.

77198 F.2d 46 (8th Cir. 1952).

78173 F.Supp. 893 (E.D. Mo. 1954). 
allocate the amount to another form of consumption. In Feinstein, on the other hand, the taxpayers, "faced with warning of loss and in possession of knowledge of how to prevent it, elected not to act"; 79 in theory, it seems fair to say that their anticipated use differed significantly from Rosenberg's. Under this approach, the result in Durden ${ }^{80}$ was correct, since the taxpayer inquired as to the danger of building in the area and complained to the quarry about its blasting operations, but not that in Appleman, ${ }^{81}$ since the possibility of elm disease was not anticipated at the time of purchase of the property and the taxpayer was powerless to prevent its occurrence.

The practical difficulties of this approach should be evident from subjecting Matheson ${ }^{82}$ and $H e y n^{83}$ to similar analysis. In these cases, the only aspect of the taxpayer's behavior that would indicate a choice to consume abnormally was their decision to place their homes precariously. Basing a decision on deductibility on this initial choice, however, would require the courts to make normative assessments of different modes of personal consumption that would be inconsistent with the accepted view that such consumption, unlike business expenditures, cannot be evaluated according to an objective norm. It is presumed that a businessman's decisions are motivated by a desire to maximize profits, ${ }^{84}$ but there is no parallel personal consumption motive.

Furthermore, such an approach would present insuperable administrative problems. In most cases there would be no tangible evidence pointing to a specific use of the property, requiring the courts to invoke some arbitrary standard. Indeed, in most cases, the obvious election would be a decision to insure; but considering failure to insure determinative would defeat the purpose of the provision-to compensate for otherwise uncompensated losses. Finally, a choice with respect to consumption that would permit deductibility might be an inefficient one. For example, the taxpayer in Heyn inquired as to the suitability of the hillside for building. Arguably, this shows that he made a conscious choice by indicating that he expected the home to stand for a long time. A reasonable man, however, might have made a more extensive inquiry

79 Id. at 895 .

803 T.C. I (1994).

81338 F.2d 729 (7th Cir. 1964).

8254 F.2d 537 (2d Cir. 1931).

8346 T.C. 302 (1966).

84 The profit motive is strong enough to characterize the purpose of anyone who invests in a corporation, regardless of his primary goal (such as control of management). Weir $v$. Commissioner, 109 F.2d 996 (3d Cir. 1940). In V.H. Monette \& Co., 45 T.C. 15 (1966), the profit motive was challenged with reference to the taxpayer's "hobby farm"; evidence of large losses year after year led the court to deny a deduction under $\$ \$ 212$ and 165 . The court held that the profit motive need not be reasonable but that it must be held in good faith. 
and taken precautionary steps beyond those the claimant took. To utilize a tort standard, however, is to distort the purpose of the subjective approach to the casualty loss. The degree of care the taxpayer shows is not the issue, but rather whether he did or did not choose to use his property in such a manner as to make the casualty a normal consequence of his intended use. This may be demonstrated by conduct which would be called negligence or gross negligence in other situations, but not necessarily. Nor does a tort approach give any weight to the opposite situation-where the taxpayer elected to preserve his property. It is the election, rather than the standard of care he in fact demonstrates, which is important. And this election is difficult to prove.

Given the difficulty of distinguishing exceptional from ordinary losses, the gloss placed on section 165 (c)(3) by the courts has not produced disturbingly inequitable results, despite the tendency of some courts to apply labels rather than analyze the facts of cases. In assessing the merits of the suddenness test, it should be borne in mind that the entire casualty loss section was probably originally designed to mitigate only a relatively small number of losses, its unsatisfactory wording makes expansion by the courts difficult, and any such expansion might result in sacrificing more of the progressivity of the rate structure for a policy of doubtful validity. Limiting deductibility to losses which involve a sudden force probably restricts allowable deductions to those which are clearly contrary to the expectation of the taxpayer, as indicated by his election as to use of his property.

Two exceptions to a rigorous application of the suddenness test, however, do seem worthwhile. First, it is apparent that the loss casesparticularly loss in shipment-may represent an exception to the statement that suddenness is a sufficient test of consumer expectations. It would seem possible to define an exception to the suddenness test where the taxpayer, though he anticipated a probability of loss, had no reasonable alternative to the use of his property which he chose to make. This differs from a broad definition of an objective norm for consumption. For example, it hardly takes behavioralist insight to realize that a homeowner has very little alternative to shipping his household goods when he changes residence. It seems anomalous in the extreme to deny him a casualty deduction if the goods are lost by the moving company, but to allow him one if the truck is wrecked en route, resulting in damage to the goods. In both cases, the only reasonable precaution he can take is to insure, but generally available insurance provides only very limited compensation. To be sure, there are proof of loss and valuation problems, but these are best met, as suggested above, through case-by-case determination rather than categorical exclusion.

Second, in close cases, the taxpayer's behavior should be considered 
relevant. Where the taxpayer has demonstrated unusual concern for his property, as in Durden and perhaps in Rosenberg, a deduction may well be justified. A subjective test of this sort should not seriously undermine an objective approach to section 165 (c)(3). Rather, it would lesșen the capriciousness of the section in marginal cases.

\section{ConGLUSION}

The casualty loss deduction is a curious provision. Under it, a taxpayer whose home is destroyed by a storm receives a deduction; one whose home deteriorates due to defective construction does not. It seemingly rewards negligence and risky consumption and penalizes prudence. While it presumably exists to mitigate the harshness of certain losses, there is no rational connection between this policy and the favored modes of destruction; neither "fire, storm, shipwreck," or the judicially-defined "other casualty" is explicable on policy grounds. These shortcomings argue strongly for modification or elimination of the section.

The courts have done reasonably well in defining the scope of the present provision. If they are to be criticized, it should probably be for providing too much law, rather than too little. They sometimes rely on casualty doctrine rather than burdens of proof, apply labels rather than make findings of fact. In general, however, the suddenness test they have developed has proved reasonably sensible, despite its lack of theoretical underpinnings. In the absence of legislative amendment of section $165(\mathrm{c})(3),{ }^{85}$ its use, and the continued development of modifications for those rare cases where it is not enough, should adequately define the scope of the deduction.

\footnotetext{
85 As is pointed out in the Report of the Royal Commission on Taxation:

[A] tax system that permitted the deduction of such losses [i.e., those caused by destruction or "casualty"] should logically allow the deduction of expenses incurred to reduce the amount of these losses. Any listing of such expenses would be lengthy, and the administration of such an allowance would be complex and uncertain. 3 Report of the Royal Commission on TAXation (CANADA) 360 (1966). As a result, the tax reform suggested by the commission would disallow all losses on property held for personal use.
} 